\title{
The Development of Saudi Arabia in King Fahd's Era
}

\author{
Abdulmohsen Al Saud ${ }^{1}$ \\ ${ }^{1}$ King Saud University, Saudi Arabia \\ ${ }^{2}$ University of Exeter, UK \\ Correspondent: Abdulmohsen Al Saud, King Saud University, Saudi Arabia. E-mail: \\ abdulmohsenalsaud@gmail.com \\ Received: November 1, 2017 \\ Accepted: November 17, 2017 \\ Online Published: January 2, 2018 \\ doi:10.5539/ach.v10n1p48 \\ URL: http://dx.doi.org/10.5539/ach.v10n1p48
}

\begin{abstract}
This article explores the development of Saudi Arabia during King Fahd's era through research which highlights the challenges and reasons behind the decline in achieving five year plans. Saudi Arabia is one of those Middle Eastern countries, based on a traditional Islamic Law system, where the process of innovation is extremely slow. The purpose of the study was to focus on the policy implementations and improvements effected during the era of King Fahd and how they changed the economy of the Kingdom. The study also uncovered some of the achievements and limitations of the initiative to educate women in their chosen fields. The impact of the innovative development plans were explored, with education, industrial development, and trade identified as core focuses during the King Fahd era. The focus on these three aspects essentially resulted in the development of Saudi Arabia's economic processes, although some failures suggested the need for further improvements through the application of new strategies. Moreover, there was a need for developmental procedures in education, industry and trade areas that ultimately affected the economy of the Kingdom.
\end{abstract}

Keywords: Agriculture, Education, Health, Industry, Political, Shura

\section{Introduction}

In $20^{\text {th }}$ century, the unification of the Kingdom of Saudi Arabia (KSA) was observed under the reign of King Fahd and the steady development of Saudi infrastructure, which is considered to be the backbone of the Kingdom's story. The era of King Fahd is regarded as having been important in transforming KSA from a predominantly rural society into a contemporary urban society, which plays a vital role in regional and international politics (Taheri, 2005). Scholars who consider the history of nations and civilizations along with their different systems, eras, races or cultures, have one common feature: they all include the existence of prominent personalities and distinct leaders. From this perspective, King Fahd, the late King of Saudi Arabia, is always recognized as the nation's distinct leader and prominent personality. Thus, the research reported here focused on how far the KSA developed during the reign of King Fahd. A key aim was to consider whether or not there was any passivity during his governance. This objective was achieved through examining five main domains: education, industry, commerce, health and social care, and the political system. Criticism made during the reign of King Fahd was then reviewed before advancing a concluding assessment.

\section{Historical Background}

Historical events and actions play a major role in any country in terms of shaping the ways in which success and prosperity in various spheres can be achieved. Therefore, it is necessary to understand the historical background related to the establishment of Saudi Arabia. In this regard, it is widely understood that the era of King Abdul Aziz was the foundation for Saudi Arabia's development. On the $23^{\text {rd }}$ of September 1932, King Abdul-Aziz announced the foundation of the Kingdom of Saudi Arabia (KSA), and this day has become Saudi Arabia's National Day (AlRasheed, 2010). Following the foundation, King Abdul-Aziz focused on the construction and organization of the state. He developed the Islamic legislation which is now considered to be the constitution of the Kingdom. A committee was established for the promotion of virtue and protection from vice and the formation of the consultative assembly (Shura). Similarly, King Abdul Aziz also established the council of ministers and worked on promoting agriculture, resettling the nomads, opening schools, and constructing roads (Al-Ofok, 1995). Fahd bin Abdulaziz was born in Riyadh, and was later called King Fahd when he became the king. The character and personal skills of King Fahd were refined by experiencing different government jobs, which subsequently led to his becoming the King of 
Saudi Arabia. Prior to his time in power, Fahd also played an essential part in Saudi Arabia's governance (Rashid \& Shaheen, 1987). The important posts he held were: Minister of Education (1953-1960), Minister of Interior (19621975), Second Vice President of the Council of Ministers (1967-1975), Crown Prince and the Vice President of the Council of Ministers (1975-1982) and, finally, King of Saudi Arabia (1982-2005).

\subsection{Contribution in Education}

During King Fahd's reign, education was staunchly emphasized as one of the basic aims of the Kingdom's developmental plans (Rashid \& Shaheen, 1987). Government statistics show the extent of the educational developments, expanding to cover most of the Kingdom's cities and villages. There is an observable increase in the number of schools and colleges from 3,283 in 1969 to 22,770 in 1999. This steady increase in the number of schools was due to the growth of students in public education. In 1969, the total number of students was 547,000. By 1999, this number had jumped to more than 4.8 million. This surge led to an increase in the number of teachers, from 23,100 in 1970 to 354,800 in 1999. Another effect of the rise in the number of students was an increase in graduate students, especially in the high schools where the number went from 2,806 in 1970 to 15,568 in 1999 (i.e. the average annual growth rate in the previous 29 years was $14.8 \%$ ).

Table 1. Statistics for Educational Institutions and Students for the period 1969-1999 (Rashid \& Shaheen, 1987)

\begin{tabular}{lll}
\hline Year & Number of Educational Institutes & Number of Students \\
\hline 1969 & 3,283 & 547,000 \\
1999 & 22,770 & 4.8 Million \\
\hline
\end{tabular}

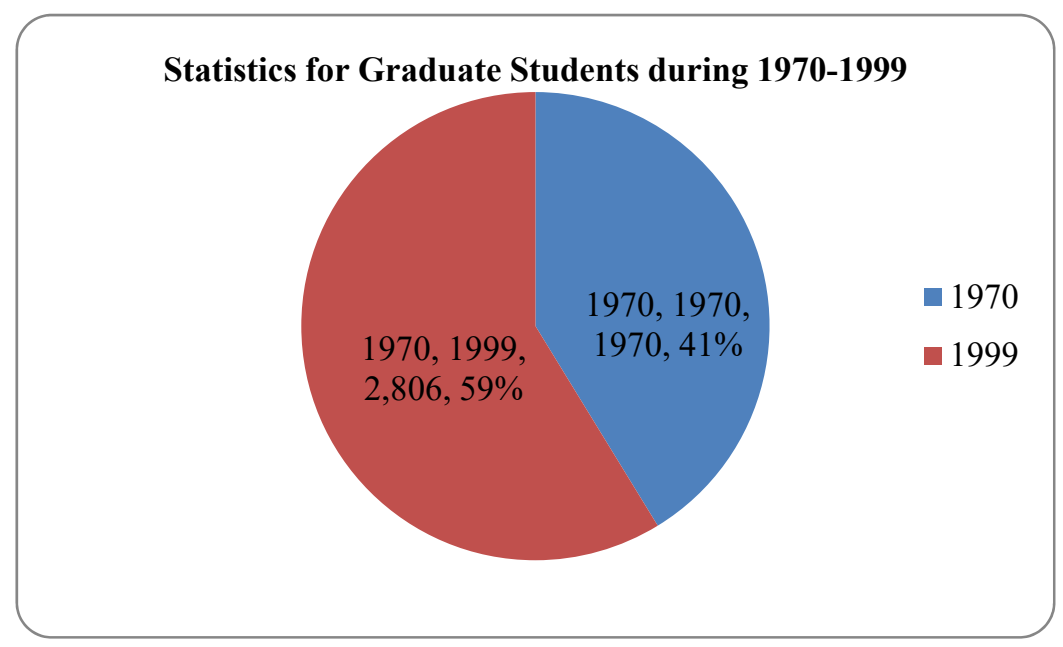

Figure 1. Statistics for Graduate Students for the period 1970-1999 (Rashid \& Shaheen, 1987)

Saudi Arabia started developing rapidly as the number of students joining the technical institutions increased from 840 in 1970 to 33,800 in 1999. As a consequence of the focus on education, Saudi Arabia experienced a rapid rise in the number of students graduating from high school and technical institutes. The number of universities then expanded and higher education has become a high priority of the government (Assmari \& Aljihami, 2016). Some of the universities enhanced Saudi Arabia's place in the region. For example, the Islamic university, attended mostly by students from an Islamic background, had a large impact on the Islamic world through its religious education. In addition to the universities, there are other educational activities occurring in colleges, such as the affiliation of colleges with the general presidency for the education of girls. This also includes teacher training colleges, which are under the Ministry of Knowledge, and the institution and colleges affiliated with the Ministry of Health. It is vital, here, to mention some of social and political events that occurred in order to evaluate how they impacted on the position of Saudi women, before considering the role of women in education. During the 1970s, the revenue generated by oil brought about the large-scale dynamics that etablished education for both males and females. There is a clear link between the broadening of education and the rise in revenue gained from oil. The Ministry of Education, being under the Department of Religious Guidance, administered education for both boys and girls at elementary level. This ensured that the main reason for the education of women was to make 
them good wives, daughters and mothers. At the same time, a key purpose for expanding education to females was to make them talented enough for jobs, such as teaching and nursing, which are viewed as being in accordance with their nature (Hamdan, 2005).

\subsection{Research Questions}

1) What were the developments that happened during King Fahd's era? And what were the barriers and lessons learnt?

2) What were the achievements and limitations of the initiative to educate women? What were the factors of success?

\section{Theoretical Background}

The era of King Fahd has been determined as a time of economic as well as industrial wellbeing for Saudi Arabia. Before King Fahd's reign, the Kingdom had faced serious economic constraints because of a major rise and then fall in oil prices (which generates Saudi Arabia's revenue). During the governance of King Fahd, however, the economy of Saudi Arabia became vibrant due to the implementation of new policies affecting industrialization, diversification, and privatization (Akeel, 2005).

The industrial sector was prioritized in the King Fahd era and that evidently contributed to its success. The industrial contribution is evidenced in GDP figures which show its rate as 2.5\% in 1969 and leaping to 6.7\% in 1999. This was a result of the state support offered to this sector, which took the form of generous loans to ensure economic activities. For this reason, the Saudi developmental fund was established, which played a vital part in promoting economic projects in the private sector. In 1969, government expenditure on these economic projects was SR 35 million. By the end of 1995, this had jumped to SR 19.5 billion. This financial support was offered to large economic projects and produced a 55-fold increase in investment capital in the period from 1969 to 1995 . The support was reflected also in the increased number of factories and factory workers. The number of public and private factories increased from 199 in 1970 to 3,163 in 1999. Furthermore, the number of factory workers augmented sharply in the same period from only 14,000 workers in 1970 to 291,600 in 1999 (Assmari \& Aljihami, 2016).

Table 2. Increase in the Private and Public Factories and Number of Workers (Assmari \& Aljihami, 2016)

\begin{tabular}{lll}
\hline Year & Private and Public Factories & Number of Workforce in Factories \\
\hline $\mathbf{1 9 7 0}$ & 199 & 14,000 \\
$\mathbf{1 9 9 9}$ & 3,163 & 291,600 \\
\hline
\end{tabular}

There are two pillars on which the industrial sector of Saudi Arabia is based. The first and main one is represented by the huge industrial cities and towns, and is usually centered on hydrocarbons. The second pillar is the manufacturing sector. The Saudi Basic Industries Corporation (SABIC) products are the part of industrial production in Saudi Arabia that is comprised of heavy metals, gases, biochemical products, plastics and fertilizers. In the industrial sector, SABIC is a prominent landmark and it is evidence of the height that the country has reached through its comprehensive renaissance. SABIC has proved to be efficient and thus successful in achieving its original objective of creating a solid base from which to enlarge the manufacturing sector.

The Ministry of Industry and Electricity licenses the products of the plants and the factories. Furthermore, the factory investors have been encouraged by the Kingdom's administrative establishment of the industrial developmental funds. The government has provided many incentives in the industrial cities, favouring the factories and their products, and offering training grants. The government provides them with allowances to rent land and recommends the use of the factory products. These plants produce a range of products including building materials, cement plastics, leather, clothes, food and glass. The factories are totally dependent on the local market in order to sell their products and the local market consumes most of them.

Small workshops and factories are provided with the license to work by the municipal government and commercial records are kept by branches of the Ministry of Commerce. Generally, these factories do not require expensive facilities nor a large amount of equipment or large buildings, so they are self-financing. The Royal Commission and the Ministry of Industry and Electricity in Jubail Ana Ynb'a carry out the planning and operations management for public projects, and the planning for private projects. The Ministry of Industry and Electricity plays a major part since it finances the projects in the private sector and it issues the industrial license to the factories. The Ministry is also required to ensure investor sustainability in the industrial sector, so it established several industrial cities that provide the basic infrastructure. These cities were established in Jeddah, Riyadh, Qassim, Mecca, 
Dammam, Ehssa, Khamees mushayt, Aseer, Madina Monawra, Tabouk, Ha'ail, and Aljouf (Assmari \& Aljihami, 2016). The Ministry needs to support economic growth by ensuring investment opportunities are available for everyone, and offering services for the investors, such as making available parcels of land that are necessary to build their industrial factories. Accordingly, they only charge nominal rents that do not exceed SR8 cents for each square meter. In addition, these cities grant investors many privileges. The most important of these provide: essential facilities, such as water sewage, electricity, communication networks, and paved roads; some technical workshop services, such as the manufacturing of spare parts that are required by the factories; and basic services, such as banks, mail services, police stations, medical clinics, cafeterias, mosques, and fire stations.

The state recognized the Royal Commission of Jubail and Ynb'a in 1975 as being in charge of developing, creating, managing, and operating all the essential rights needed to create two modern industrial cities that have independent strengths. King Fahd was the chairman of the Commission. The two industrial cities are believed to be distinct in the history of global modern development. This is because they were planned with unique and specific methods for production. These cities offer a good example of the innovative establishment of industry as well as the longterm vision of the Kingdom's economic future (King Abdul-Aziz Foundation, 1999).

\subsection{Success in Trade}

The trade in imports and exports has been affected positively by the growth in the industrial sector. The Kingdom was transformed from a trading nation limited by its dependence largely on the seasons, into one based on stable economic pillars, such as the pilgrimage season. The balance of trade achieved a surplus of SR45.5 billion in 1998 . The export rate decreased in terms of trade from SR124.5 billion to SR105 billion in 1999. The Kingdom was transforming from a primarily importing state, to an independent state, and a state sometimes exporting the surplus products and goods (Ministry of Foreign Affairs, 2010). The state - represented by the Ministry of Commerce, the Ministry of Industry and Electricity and the Saudi Ports Authority - supported the trade sector (Developmental activity of the fund, 1970-2008). Consequently, this sector achieved steady growth at several stages, in terms of direct support from the state's policy through the Industrial and Agricultural loans, Saudi Credit banks and the Chamber of Saudi Consultancy Services. This support has played an effective role in giving rise to a trade renaissance in the Kingdom.

Ports also played a major role in the developmental progress of the territory. In 1976, the Saudi Port Authority was established to carry out the task of improving Saudi ports, by increasing their operational efficiency in order to cope with exports and imports and meeting the obligations of the developmental plans. Fortunately, this Authority proved its success by achieving its goals; the Saudi ports became the link between the national economy, with its various resources, and the international economy. The Authority's projects have solved many problems faced by the trade and industrial sectors. These problems were related to the long waiting period of vessels at sea and the late arrival of ships because of the small size of the ports and their lack of sidewalks. These issues were found to have a negative impact on the trade sector. Furthermore, the Authority solved the problem of accumulated cargo by rearranging the ports according to new operational methods. The Authority was able to successively achieve its goals through using newly developed technical methods in operating and managing the ports and through increasing the number of sidewalks. Statistics show that the number of sidewalks in the Kingdom's ports (which were built especially to transport industrial products) increased from 27 in 1975 to 183 in 1999. Out of these, 23 are in the King Fahd industrial port in Jubail and another 23 in the King Fahd industrial port in Yunb'a. Requirements to protect the marine environment from pollution were not ignored by the Authority, so the ports were provided with enhanced equipment for controlling pollution and protecting the environment. The Saudi Port Authority is in charge of eight industrial and trade ports on the coast of the Arabian Gulf and the Red Sea. These are the Jeddah Islamic ports, King Abdul-Aziz port in Dammam, Aljubail commercial port, Ynb'a commercial port, King Fahd industrial port in Ynb'a, Jazan port, Daba port (the latest port opened in 1994), and King Fahd industrial port in Jubail (King Abdul-Aziz Foundation, 1999). Moreover, there are some trade goals and objectives set by the Kingdom to lessen the dependency on the market of oil, limit economic vulnerability and activate decentralization for private performance associated with the market economy. Three-prolonged techniques have assisted the Kingdom in accomplishing much in its trade policy: taking part in the World Trade Organization; fostering the transfer of technology and domestic economic stimulus; and privatizing core government services by initiating domestic programs (Taheri, 2005).

\subsection{Development of Agriculture and Food Security}

The agricultural sector is considered to be the most successful sector in Saudi Arabia. Programs and projects have been initiated by the government in order to enhance the production of agricultural products (WTO, 2011). The significant care and attention given to the development of agriculture and food security occurred during King 
Fahd's era. Indeed, the past and present improvements in these sectors have staggered observers and scholars. Solid research and planning was required to support the environment and enable the Kingdom to transform the driest deserts of the Arabian peninsula into large green farms in a relatively short span of time, probably less than a quarter of a century. Under King Fahd's governance, the state showed its deep concern for, and interest in this division by directing the Ministry of Water and Agriculture to plan and execute agricultural projects. Additionally, the state constructed dams, distributed land to farmers, reclaimed land and drilled wells. It also established the Saudi Agricultural Bank (SAB) to provide services to investors and farmers. The developmental march of the Kingdom in terms of agriculture has been strengthened by the participation of SAB. The total amount of loans given to farmers by the SAB was SR16.6 million in 1970, but it jumped to SR903 million in 1999. During the third and significant developmental phase, these loans reached their highest rates in 1980, when the total was approximately SR2.3 billion, in particular to enable completion of the infrastructure of the various developmental projects. The loans were distributed by branches of the Ministry of Agriculture and provided the state with farmers, along with agricultural equipment including irrigation pumps. Also, agricultural engineers, who are present in all branches of the Ministry, took care of the methods of production, as well as pest control. Plus, in order to provide water for the farmers, the state constructed many dams the most famous of which are:

1) Jazan valley's dam, which was opened by King Fahd when he was the Minister of Interior in 1971.

2) Najran valley's dam that was opened by Prince Naif Bin Abdul-Aziz, the current Minister of Interior, in 1982.

Five dams were constructed in the capital city of KSA: nemar dam, elelab dam, hanifa valley dam, laban valley dam and alhaer dam. An irrigation and drainage project was developed in ehssa'a by the Ministry of Agriculture. The main purpose of this project was to obtain spring water, storing it, as well as dividing it, according to the land's requirements. New crops have been introduced and more land reclaimed from the augmentation of this project. The development of this initiative was at its zenith when the theory of food self-sufficiency was applied in KSA by King Fahd. Furthermore, other associated projects progressed the development of dairy, poultry and fish farms (Ministry of Higher Education). With regard to the seventh development plan, the objective of KSA was to produce sustainable agriculture. The Kingdom's strategies entailed extending the agricultural programs in this context. It was necessary for the government to draw on existing knowledge to achieve the task. They investigated the link between the production of safe, healthy and abundant food with sustainable agriculture by means of the proper channeling of natural resources. The use of natural resources in order to enhance quality of life, and increasing income levels, was the focus of the seventh development plan of government. It also concentrated on raising the awareness of farmers about the importance of water transformation. At the same time, dates, winter wheat, vegetables and citrus fruits were considered to be important crops, and were therefore included in the agriculture plans. In regard to the health of people, the government of Saudi Arabia has concerns about the sustainability of these crops as they are being influenced by the extreme climatic conditions. In order to minimize these hazardous climate changes, the government is still focusing on the irrigation strategies (Alkolibi, 2002).

\subsection{Health and Social Care Domain}

During the era of King Fahd, a private organization was employed by the Ministry of Health of Saudi Arabia in order to promote an education program for healthcare. This healthcare and social program was rolled out in more than $85 \%$ of the hospitals of Saudi Arabia (King, 2005). The number of hospitals increased from 47 in 1970 to 186 in 1999. In addition, the number of health centers jumped from 519 to 1,756 in the same period. Accordingly, the number of beds in hospitals increased from 7,165 to 27,794 and the number of doctors increased from 789 to 14,786. Also, the number of nursing staff increased by 2,253 to 36,340 and the number of pharmacists rose from 1,396 to 22,188 . Moreover, the Kingdom's hospitals have achieved outstanding results, with many complicated surgeries (such as open-heart and liver implant surgeries) performed successfully at the hands of Saudi doctors. Also, a fleet of 17 planes has been specially equipped to be flying hospitals that carry the wounded and the ill and take care of them until they arrive at the destination hospitals. These flying hospitals are able to fly long distances to connect patients to any place in the world (Alkolibi, 2002). The duties of the Health Ministry include taking care of Saudis who have special needs, such as the elderly, orphans, disabled people and juveniles. The number of foundations in charge of these people reached to 95 in 1995. By this time, there were 16 orphanages, 22 houses for juvenile delinquents, 5 nurseries to take care of children with special needs, 22 rehabilitation centers for the disabled, 10 nursing homes for elderly care, and 20 women's associations. In addition, the state set up various measures to help the poor, such as regular social security benefits, which increased from SR39.4 million in 1970 to 2.6 billion in 1999. Also, the state increased spending on interim relief from 2.3 million in 1970 to 398.9 million in 1999 . 


\subsection{Political Development}

The state system was established in the era of King Fahd. This comprised the Basic Government System, the Regional system and the Shura Council. The main aim was to draw on what was already there, and to prepare for the future on the basis of what was observable in the present. Since the establishment of the Kingdom by King Abdul Aziz, this system had formed the basis of the government with regard to Islamic legislation, and it was also adopted by Fahd's government, for more than six decades. In Fahd's era, the Kingdom had a high degree of prosperity and development as a consequence of these systems and the citizens aquired what they actually needed including security, prosperity, stability and happiness. The implementation of these governmental systems in their comprehensive versions went hand-in-hand with the huge development witnessed by the Kingdom. It was essential to provide the necessary flexibility to conduct the management and affairs of the citizens, and outline their duties and responsibilities, as well as govern seamlessly.

King Fahd explained almost everything regarding his system in a heart-to-heart speech to his people, presenting the significance of the system of the Shura Council and the basic governance. King Fahd was among the talented administrators, who was responsible for initiating significant industrial developments in Saudi Arabia. He was the one who issued numerous decrees that outlined the basic statutes of government including the councils at the emirate and provincial levels. Moreover, reforms to prohibit conflict of interest for high level officials and ministers were announced in the era of King Fahd.

\section{The System of Basic Governance}

The system of basic governance has given the country its official characteristic; therefore, the Kingdom has had this character since 1932, but this system has also provided the constitution that identifies the aims, duties and working mechanisms of the State, and guidance for them. According to the general guidelines set by King Fahd, it was determined that KSA is a sovereign Arab Islamic state. The religion followed by the KSA is Islam, and the national language is Arabic. The system of basic governance has identified the respective roles of the King and Crown Prince: the King as the source of authority and the Crown Prince as his deputy (Al Saud, 2000). It also identified the three governance authorities and made them independent of each other. Moreover, the governance system in KSA is to be based on justice, equality, and consultation on the basis of the laws of Islam.

\subsection{The Importance of the Shura's Council System}

A Royal decree was issued by King Fahd, which approved the new system of Al-Shura Council. This Council comprised 60 members, appointed by, at that time, King Fahd. Al-Shura Council is now seen as enjoying the same authority as Western parliaments. Hence, the Kingdom of Saudi Arabia is observed as having adopted a democracy, which is free of negativities (The Shura Council, 2016). The monopoly of the Council of Ministers came to an end as a legislative authority by the reactivation of the Council of Shura. An institution was provided by the Shura Council system to monitor the government's work. The new laws of Shura Council since King Fahd's era provide for the establishment and modernization of existing systems by integrating the framework of Al-Shura. This framework is beneficial in providing new opportunities for the ambitions of elites by giving them a chance to participate in political activities (Al-Rasheed, 1996).

\subsection{Criticism of Shura's Council}

The Shura Council has been criticized for a lack of interaction with the problems, needs, and critical issues of Saudi Arabian society, though this has been blamed upon its restricted authority. Some specific arrangements have been made by the Shura Council which enable citizens to visit Shura and make themselves familiar with the equipment and utilities of Majlis Shura. One of the major criticisms, however, is that the Shura Council is not provided with the necessary funds to improve its work. There are not enough trained staff supporting the Council members. This has contributed to reducing the quality of the performance of their work (Ramady \& Saee, 2007).

\section{An Overall Evaluation of the Era}

In spite of all the achievements that have been observed in the reign of King Fahd, the Kingdom of Saudi Arabia also faced some issues at that time. The pairing of politics and commerce led to the engagement of many politicians, including members of the royal family, in the trade field and they started competing over winning government tenders. This caused a low level of services because those in charge of these tenders might have overlooked some of the specifications required in order to give the project to this person or that. Moreover, the government took a long time to legislate against corruption (Cordesman, A. H., \& Obaid, 2005). Although there were five-year developmental plans, these were not informed by a long-term vision. This long-term vision plan provides a basis to assess the features and objectives of the state in the long term, which might lead to over-consumption of resources and capabilities. Moreover, these five year plans have not been able to achieve one of the most important 
goals for which they were set up. The diversification of income resources, as a aim, was part of the Saudi five year plans from the first. However, the state could not achieve this objective as a result of the lack of long-term vision, which affected the ability of the state to establish proper standards and regulations to evaluate and control the progression and acheivement stages. The express result for KSA was that a decrease in oil prices exposed the state to financial crisis. Thus, the state experienced a budget deficit for many years. Yet, the state has learned the lesson (Ministry of Economy and Planning, 2016) in part and, therefore, has tried to solve the problem by establishing a fund for financial reserves, such that the fiscal surplus is transferred and kept in case of any deficit.

There were very ambitious projects built to meet the needs of the state in its strategy to be self-sufficient in producing food. This strategy represented a real revolution in the Kingdom's agricultural sector since it was provided with manpower and involved a huge expenditure of money. The strategem had wider goals than the state's self-sufficiency in producing food; these involved expanding the middle class and promoting the policy of resettlement of the nomads. This policy was built upon solid studies, but was misunderstood. Research indicated that there was an underground river whose water exceeded the capacity of the Nile (Al-Jazeera, 2010). This information caused the government to adopt a strategy; however, it did not realize that the groundwater was so deep that its extraction would be more expensive and non-economic than the desalination of seawater. The government started a big agricultural project, which led to water usage ten times that of the renewable water resources in Saudi Arabia. As a result, the high consumption has been observed to influence the level of groundwater (FAO, 2009). A decline, following King Fahd's development plan, has also been seen in the per capita income of Saudi Arabia, as the population has surged and opportunities for employment have diminished (Al-Ghamdi \& Al-Saddat, 2002).

Despite the fact that higher education in the kingdom was strong; it was not able to fulfil the requirements of the labor market (Martin, 2005). Just 13 percent of the jobs in Saudi Arabia were filled by Saudis while the rest were covered by foreign labor (Cordesman \& Obaid, 2005). Moreover, the government failed to solve the unemployment problem, by not preparing society to accept and respect working in many occupations, such as manual labor, as well as not having a system that could organize the competition between citizens and foreign workers. Millions of foreigners were, and continue to be employed by Saudi Arabia, while Saudi citizens remain unemployed due to social mores and a lack of capabilities. At the same time, the economic recession caused by oil market crises prohibited organizations from hiring, which in turn resulted in increased unemployment (Wilson, 2004).

Development in Saudi Arabia is strong and comprehensive, but incomplete. The greatest defect is that it has relied on foreign labor, which has created an imbalance between the existence of a comprehensive renaissance and a high rate of unemployment (Al Rasheed, 2010). Because of the above problems, the state has been unable to solve some of its on-going social problems, such as poverty and unemployment, despite the comprehensive development, and this has put pressure on the government (Wilson, 2004). Although there has been reflection on the massive change that has happened in Saudi Arabia during the King Fahd era, it is not commensurate with the volume of expenditure in the same period.

\subsection{Barriers to Development}

- The following are the most important barriers, which have contributed to slowing down the development progress:

- Public awareness of the importance of cooperation between the general puplic and the government for successful achievement.

- Cultural, tribal values, and religious limitations.

- $\quad$ An unorganized mix between the public (governmental) and private sectors.

- $\quad$ Lack of national technical experience.

- Unemployment.

- Higher education research topics not much related to Industrial Technology, societal cultural and environmental developments.

- $\quad$ No effective policies to nationalize skilled and unskilled labor involved in these initiatives due to the lack of societal culture and skilled technicians.

\subsection{Factors of Success to Achieve Women's Education}

Many factors may have contributed to this success. One factor is governmental awareness of cultural needs for educated women, which can consequently contribute to overall development. The government in this sense has realized that policies are needed in order to neutralise between the general need in the higher education sector and 
cultural relgious limitations. The government has therefore put forward polices in order to play a role against any barrier that might appear during the strategy implementation.

\section{Conclusion}

This study of the development of Saudi Arabia during the rule of King Fahd began by providing its historical background and further explained the development relating to education at various levels. Nevertheless, the efforts made did not match the graduate requirements of the labor market. The developments in the industrial, agricultural and trade sectors were highlighted. Although massive changes were observed, no explicitly long-term plans were fostered in order to guide the country towards the stated objectives. The aims were too broad and led to strategic failures, resulting in the consumption of a large part of the state's resources. However, the health and social care sectors showed some undeniable progress. The core aspects during King Fahd's era were identified, which include education, trade and industrial development. In order to observe the outcomes of the development of Saudi Arabia's economic processes, these aspects were emphasized. Low levels of cooperation among government agencies, or perhaps just to say the conflict between plans, has led to the paralysis in the implementation of the development plans. With respect to Saudi Arabia's economic conditions, the decline in the prices of oil engendered economic pressures at the time of King Fahd's governance. There is a need, suggested by the failures associated with the aspects discussed, for driving further improvements through the implementation of new policies. Furthermore, education also needs to be further enhanced along with trade and industry, which may positively impact the economy of the Kingdom.

\section{Acknowledgement}

The author is very thankful to all the associated personnel in any reference that contributed in/for the purpose of this research. Further, this research holds no conflict of interest and is not funded through any source.

\section{References}

Akeel, M. (2005). King Fahd reign: An era of prosperity and industrial development. Retrieved May 24, 2016, from http://www.arabnews.com/node/270911

Al Saud, F. B. M. A. (2000). Political development in the kingdom of Saudi Arabia: an assessment of the Majlis Ash-Shura (Doctoral dissertation, Durham University).

Al-Ghamdi, A., \& Al-Saddat, I. (2002). The development of the educational system in Saudi Arabia. Riyadh: Tarbiat Al Ghad.

Al-Jazeera Net. (2010). Programs, Without Borders. Retrieved March 15, 2010, from www.aljazeera.net

Alkolibi, F. M. (2002). Possible effects of global warming on agriculture and water resources in Saudi Arabia: impacts and responses. Climatic Change, 54(1-2), 225-245. https://doi.org/10.1023/a:1015777403153

Al-Ofok. (1995). Spotlight on the achievements of development in the Kingdom of Saudi Arabia. Riyadh: Al-Ofok Press.

Al-Rasheed, M. (1996). God, the king and the nation: Political rhetoric in Saudi Arabia in the 1990s. The Middle East Journal, 359-371.

Al-Rasheed, M. (2010). A history of Saudi Arabia. Cambridge University Press.

Assmari, F., \& Aljihami, N. (2017).The Kingdom of Saudi Arabia. Ministry of Economy and Planning, The Long Term Strategy of The Saudi Economy, Development March. Retrieved from: www.mep.gov.sa.

Cordesman, A. H., \& Obaid, N. E. (2005). National security in Saudi Arabia: threats, responses, and challenges. Greenwood Publishing Group.

The Saudi Fund for Development. (2017). Developmental activity of the fund between 1970-2008. Retreived from www.sfd.gov.sa

FAO. (2009). Groundwater management in Saudi Arabia: Draft synthesis report. Retrieved from: http://www.groundwatergovernance.org/fileadmin/user_upload/groundwatergovernance/docs/Country_stud ies/Saudi_Arabia_Synthesis_Report_Final_Morocco_Synthesis_Report_Final_Groundwater_Management. $\operatorname{pdf}(2009)$

Hamdan, A. (2005). Women and Education in Saudi Arabia: Challenges and Achievements. International Education Journal, 6(1), 42-64.

King Abdul-Aziz Foundation. (1999). The Kingdom of Saudi Arabia in 100 year: Brief Information. Riyadh: AlObikan Press. 
King, J. (2005). Oil in the Middle East. Heinemann-Raintree Library.

Martin, D. (2005). King Fahd, 82, dies; guided the Saudis between tradition and modernization. The New York Times. Retrieved from http://www.nytimes.com/2005/08/02/world/middleeast/king-fahd-82-dies-guided the-saudis-between-tradition-and-modernization.html?_r=0

Ministry of Economy and Planning. (2016). The Government has started a long term strategy but still with a broad vision. The long term strategy of the Saudi economy. Retrieved May 24, 2016, from www.mep.gov.sa

Ministry of Foreign Affairs. (2010). National Day, Industry. Retrieved from www.mofa.gov.sa

Ministry of Higher Education, Atlas, Agriculture. Retrieved from www.ksaatlas.org

Ramady, M. A., \& Saee, J. (2007). Foreign direct investment: A strategic move toward sustainable free enterprise and economic development in Saudi Arabia. Thunderbird International Business Review, 49(1), 37-56. https://doi.org/10.1002/tie.20130

Rashid, N. I., \& Shaheen, E. I. (1987). King Fahd and Saudi Arabia's great evolution. Intl Inst of Technology Inc.

Taheri, A. (2005) The King Fahd era: The evolution of Kingdom. Retrieved from http://english.aawsat.com/2005/ 08/article55270551/the-king-fahd-era-the-evolution-of-a-kingdom

The Shura Council. (2016). The Saudi Network. Retrieved May 24, 2016, from http://www.the-saudi.net/ saudiarabia/shoura.htm

Wilson, R. (2004). Economic Development in Saudi Arabia (Vol. 1). Psychology Press.

World Trade Organization (WTO). (2011). Trade Policy Review Report by Kingdom of Saudi Arabia.

\section{Copyrights}

Copyright for this article is retained by the author(s), with first publication rights granted to the journal.

This is an open-access article distributed under the terms and conditions of the Creative Commons Attribution license (http://creativecommons.org/licenses/by/4.0/). 